\title{
Editorial Note: Outlook of the Review of Socionetwork Strategies: 2017
}

\author{
Yasuharu Ukai ${ }^{1,2}$
}

Received: 30 October 2017/Accepted: 31 October 2017/Published online: 13 November 2017

(C) Springer Japan KK, part of Springer Nature 2017

\section{Introduction}

The editorial board of the Review of Socionetwork Strategies received fifteen papers from December 2016 to October 2017. Thirteen papers were accepted as articles. One was rejected. One is on the process of reviewing by two anonymous referees.

I would like to review the situation of the Review of Socionetwork Strategies: RSOC, as Honorary Chief Editor of this journal.

\section{Time Series of RSOC}

The time series data of articles and notes from RSOC are described in Fig. 1. The rate of acceptance was $92.9 \%$ in 2017. The editorial board continually receives submissions related to computer science and social science from all over the world.

The submitted manuscripts were peer-reviewed by two anonymous referees. The editors at RSOC decided to accept, reject, or conditionally accept based on reports from the referees. Average review period is about 20 weeks. The longest reviewing time was 36 weeks, but this was an extraordinary case. The shortest reviewing time was 8 weeks in 2017.

Yasuharu Ukai

v751832@kansai-u.ac.jp

1 Research Institute for Socionetwork Strategies, Kansai University, Suita, Osaka 564-8680, Japan

2 Editorial Board, The Review of Socionetwork Strategies, RISS, Kansai University, Suita, Osaka 564-8680, Japan 


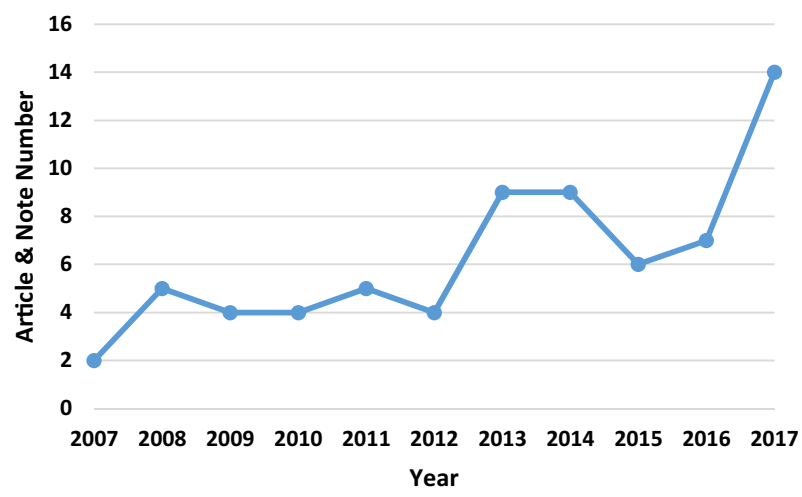

Fig. 1 Time series of RSOC articles and notes

Authors were requested to revise their manuscript according to the referees' comments, suggestions, and questions. In certain cases, the editorial board promoted a manuscript to an Article or demoted it to a Research Note. For Volume 11 in 2017, this happened once. $85.7 \%$ of the accepted manuscripts for Volume 11 were accepted conditionally. In 2017, the authors were supposed to return the revised manuscript with answers to the referees' remarks within 4 weeks. This deadline was very difficult for the authors, but a half of them succeeded within this requirement.

The affiliated institutes of authors locate in Japan, France, New Zealand, Algeria, Malaysia, and Turkey.

\section{Full-Text Article Requested}

In Fig. 2, the number of full article requests through the Internet between January 2013 and December 2016 is shown by monthly. Obviously, the academic calendars of universities effect the downloading of article requests. March shows the most downloads for PDF file article requests from scholars and graduate students all over the world.

In Fig. 3, the number of full article requests through the Internet between January 2010 and December 2016 is also shown by annually.

\section{Geographical Distribution of Downloads}

In Fig. 4, the geographical distribution of downloading article requests is reported. The editorial board is located in Osaka, Japan. Seventy-five percent of the members of the editorial board are professors affiliated with universities in Japan. Therefore, it is reasonable that almost all article requests were from the Asia-Pacific area in 2009. However, in 2016 the requests from North America and Europe have increased to $34 \%$ from $20 \%$ in 2012 . 


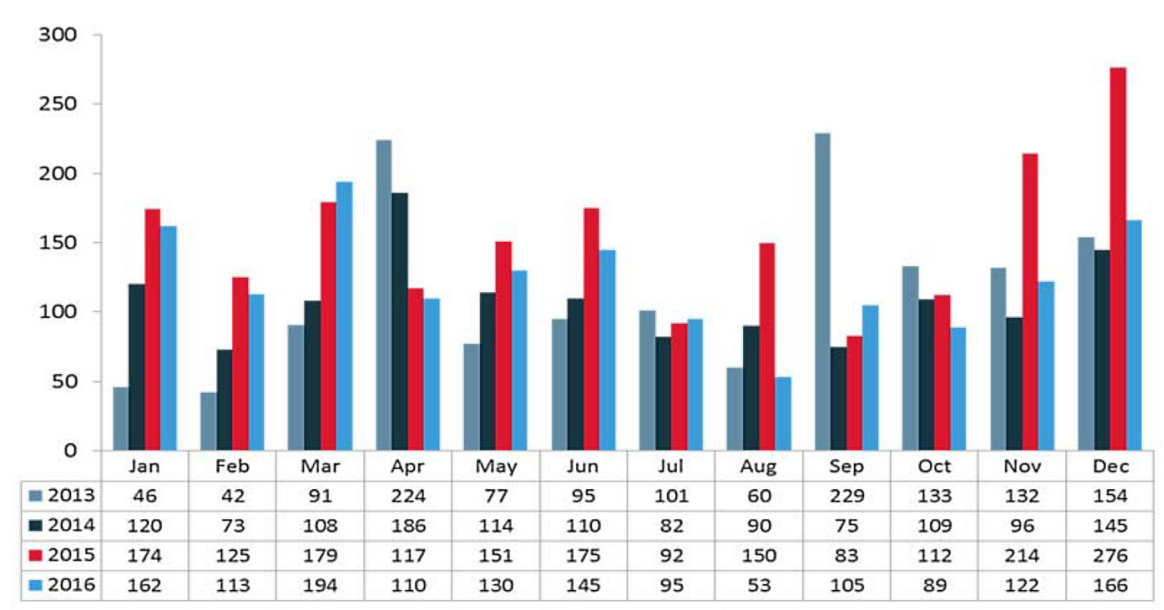

Fig. 2 Full-text article requests 2013-2016

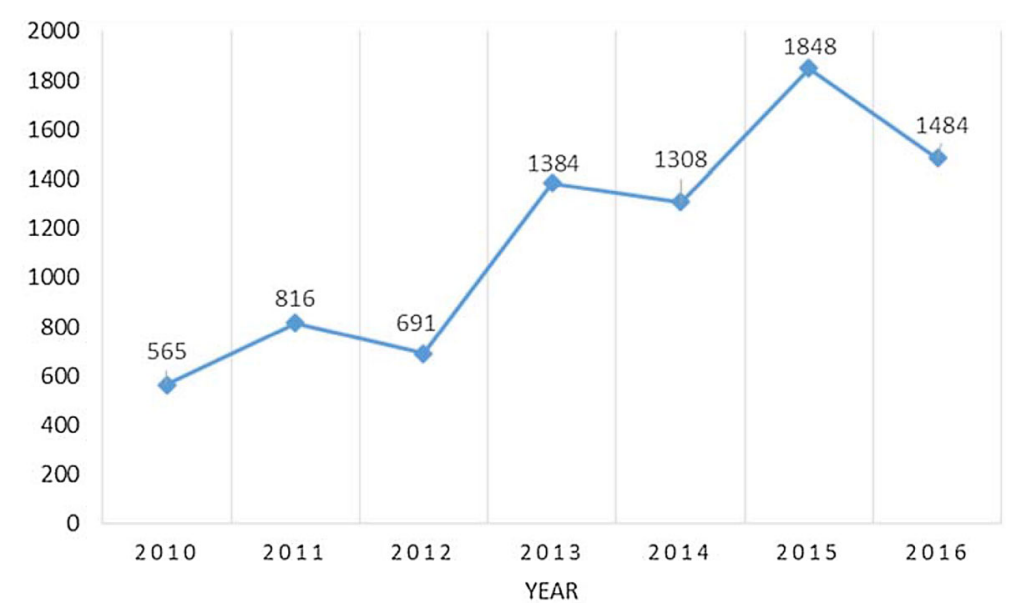

Fig. 3 Time series of RSOC full-text article requests

The editorial board is satisfied with the increasing area variety of full-text article requests, especially from Middle East, Latin America, and Africa.

\section{Rank of Articles Cited and Downloaded}

The ranking of article citations between 2007 and 2016 is described in Table 1. The top articles are by Tsumoto and Tsumoto $[1,2]$ about medical statistics. The third most cited article is by Jorgenson and $\mathrm{Vu}$ [3] about econometrics. The fourth article is by Yada et al. [4] regarding management science. The fifth most cited article is by Ukai and Takemura [5] about econometrics and computer science. The sixth articles 


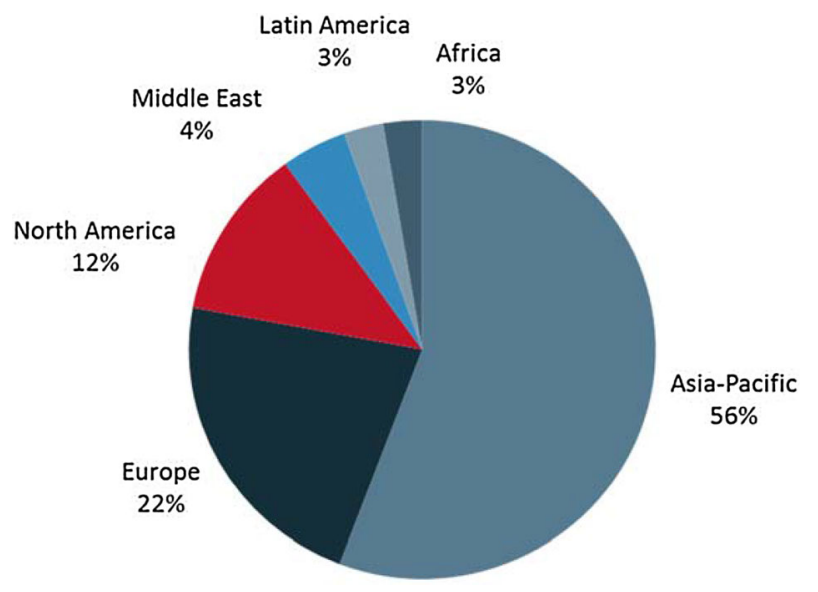

Fig. 4 Full-text article requests by geography: 2016

Table 1 Top seven articles cited in Google Scholar in October 2017

\begin{tabular}{|c|c|c|c|}
\hline Author(s) & Title & $\begin{array}{l}\text { Volume } \\
\text { (issue); } \\
\text { year }\end{array}$ & Citations \\
\hline Tsumoto, Y., Tsumoto, S. & $\begin{array}{l}\text { Exploratory univariate analysis on the } \\
\text { characterization of a university hospital: a } \\
\text { preliminary step to data-mining-based } \\
\text { hospital management using an exploratory } \\
\text { univariate analysis of a university hospital }\end{array}$ & $4(2) ; 2010$ & 36 \\
\hline Tsumoto, Y., Tsumoto, S. & $\begin{array}{l}\text { Correlation and regression analysis for } \\
\text { characterizations of a university hospital }\end{array}$ & $5(2) ; 2011$ & 36 \\
\hline Jorgenson, D. W., Vu, K. M. & $\begin{array}{l}\text { Projecting world economic growth: the } \\
\text { contribution of information technology }\end{array}$ & $3(2) ; 2009$ & 21 \\
\hline $\begin{array}{l}\text { Yada, K., Washio, T., Ukai, } \\
\text { Y., Nagaoka, H. }\end{array}$ & Modeling bank runs in financial crises & $3(1) ; 2009$ & 16 \\
\hline Ukai, Y., Takemura, T. & Spam mails impede economic growth & $1(1) ; 2007$ & 15 \\
\hline $\begin{array}{l}\text { Takizawa, A., Inoue, M., } \\
\text { Katoh, N. }\end{array}$ & $\begin{array}{l}\text { An emergency evacuation planning model } \\
\text { using the university quickest flow }\end{array}$ & $6(1) ; 2012$ & 14 \\
\hline Lin M. H., Hong C. F. & $\begin{array}{l}\text { Opportunities for crossing the chasm between } \\
\text { early adopters and early majority through new } \\
\text { uses of innovative products }\end{array}$ & $5(2) ; 2011$ & 14 \\
\hline
\end{tabular}

are by Takizawa et al. [6] of computer science, and Lin and Hong [7] regarding management science.

The variety of the academic fields has been amazing. However, all of the articles are related to computer science nowadays. 
Table 2 Top seven articles downloaded in 2014-2016

\begin{tabular}{|c|c|c|c|}
\hline Author(s) & Title & $\begin{array}{l}\text { Volume } \\
\text { (issue); } \\
\text { year }\end{array}$ & Requests \\
\hline $\begin{array}{l}\text { Thongtanunam P., Kula, R. G., Cruz, } \\
\text { A. E. C., Yoshida, N., Ichikawa, K., } \\
\text { Iida, H. }\end{array}$ & $\begin{array}{l}\text { Mining history of gamification toward } \\
\text { finding expertise in question and } \\
\text { answering communities: experience } \\
\text { and practice with stack exchange }\end{array}$ & $7(2) ; 2013$ & 248 \\
\hline Takeda, K., Takemura, T., Kozu, T. & $\begin{array}{l}\text { Investment literacy and individual } \\
\text { investor biases: survey evidence in } \\
\text { the japanese stock market }\end{array}$ & $7(1) ; 2013$ & 216 \\
\hline Satonaka, H., Sunayama, W. & $\begin{array}{l}\text { Sales strategy mining support with } \\
\text { visualization of moving history }\end{array}$ & $7(1) ; 2013$ & $137^{\mathrm{a}}$ \\
\hline Lin M. H., Hong C. F. & $\begin{array}{l}\text { Opportunities for crossing the chasm } \\
\text { between early adopters and early } \\
\text { majority through new uses of } \\
\text { innovative products }\end{array}$ & $5(2) ; 2011$ & 199 \\
\hline Takizawa, A., Inoue, M., Katoh. N. & $\begin{array}{l}\text { An emergency evacuation planning } \\
\text { model using the universally quickest } \\
\text { flow }\end{array}$ & $6(1) ; 2012$ & $112^{\mathrm{a}}$ \\
\hline $\begin{array}{l}\text { Watashiba, Y. Date, S. Abe, H. Kido, } \\
\text { Y., Ichikawa, K., Yamanaka, H., } \\
\text { Kawai, E., Shimojo, S., Takemura, } \\
\text { H. }\end{array}$ & $\begin{array}{l}\text { Efficiency analysis of a SDN- } \\
\text { enhanced resource management } \\
\text { system through NAS parallel } \\
\text { benchmarks }\end{array}$ & $8(2) ; 2014$ & 115 \\
\hline Takagi, S. & $\begin{array}{l}\text { An introduction to the economic } \\
\text { analysis of open data }\end{array}$ & $8(2) ; 2014$ & 104 \\
\hline
\end{tabular}

a2015 data

The ranking of full-text article downloading in 2014-2016 is summarized in Table 2. It is very interesting to the editorial board to see the difference between the citation and the downloading. We are waiting for the submission of statistical research concerning this time discrepancy.

Acknowledgements The author wishes to thank the technical help by Mr. Yutaka Hirachi at Springer Japan KK.

\section{References}

1. Tsumoto, Y., \& Tsumoto, S. (2010). Exploratory univariate analysis on the characterization of a university hospital: A preliminary step to data-mining-based hospital management using an exploratory univariate analysis of a university hospital. The Review of Socionetwork Strategies, 4(2), 47-63.

2. Tsumoto, Y., \& Tsumoto, S. (2011). Correlation and regression analysis for characterizations of a university hospital. The Review of Socionetwork Strategies, 5(2), 43-55.

3. Jorgenson, D. W., \& Vu, K. M. (2009). Projecting world economic growth: The contribution of information technology. The Review of Socionetwork Strategies, 3(2), 35-49.

4. Yada, K., Washio, T., Ukai, Y., \& Nagaoka, H. (2009). Modeling bank runs in financial crises. The Review of Socionetwork Strategies, 3(1), 19-31.

5. Ukai, Y., \& Takemura, T. (2007). Spam mails impede economic growth. The Review of Socionetwork Strategies, 1(1), 14-22. 
6. Takizawa, A., Inoue, M., \& Katoh, N. (2012). An emergency evacuation planning model using the university quickest flow. The Review of Socionetwork Strategies, 6(1), 15-28.

7. Lin, M. H., \& Hong, C. F. (2011). Opportunities for crossing the chasm between early adopters and early majority through new uses of innovative products. The Review of Socionetwork Strategies, 5(2), $27-42$. 